\title{
Effects of Photobiomodulation Therapy Combined with Static Magnetic Field in Severe COVID-19 Patients Requiring Intubation: A Pragmatic Randomized Placebo-Controlled Trial
}

\author{
Thiago De Marchi (D) ${ }^{1,2}$ \\ Fabiano Frâncio ${ }^{1,3}$ \\ João Vitor Ferlito ${ }^{3}$ \\ Renata Weigert ${ }^{3}$ \\ Cristiane de Oliveira ${ }^{3}$ \\ Ana Paula Merlo ${ }^{3}$ \\ Délcio Luis Pandini ${ }^{3}$ \\ Bolivar Antônio Pasqual-Júnior ${ }^{3}$ \\ Daniela Giovanella ${ }^{3}$ \\ Shaiane Silva Tomazoni (iD) ${ }^{4,5}$ \\ Ernesto Cesar Leal-Junior $2,4,5$ \\ 'University Center of Bento Gonçalves \\ (UNICNEC), Bento Gonçalves, Rio \\ Grande do Sul, Brazil; ${ }^{2}$ Laboratory of \\ Phototherapy and Innovative \\ Technologies in Health (LaPIT), Post- \\ graduate Program in Rehabilitation \\ Sciences, Nove de Julho University, São \\ Paulo, Brazil; ${ }^{3}$ Hospital Tacchini, Bento \\ Gonçalves, Rio Grande do Sul, Brazil; \\ ${ }^{4}$ Physiotherapy Research Group, \\ Department of Global Public Health and \\ Primary Care, University of Bergen, \\ Bergen, Norway; ${ }^{5}$ ELJ Consultancy, \\ Scientific Consultants, São Paulo, Brazil
}

Correspondence: Shaiane Silva Tomazoni Physiotherapy Research Group, Department of Global Public Health and Primary Care, University of Bergen, Alrek helseklynge, blokk D, Årstadveien 17, Bergen, NO-5020, Norway

Email shaiane.tomazoni@eljconsultancy. com
Purpose: We aimed to investigate the effects of photobiomodulation therapy combined with static magnetic field (PBMT-sMF) on the length of intensive care unit (ICU) stay and mortality rate of severe COVID-19 patients requiring invasive mechanical ventilation and assess its role in preserving respiratory muscles and modulating inflammatory processes.

Patients and Methods: We conducted a prospectively registered, triple-blinded, randomized, placebo-controlled trial of PBMT-sMF in severe COVID-19 ICU patients requiring invasive mechanical ventilation. Patients were randomly assigned to receive either PBMT-sMF or a placebo daily throughout their ICU stay. The primary outcome was length of ICU stay, defined by either discharge or death. The secondary outcomes were survival rate, diaphragm muscle function, and the changes in blood parameters, ventilatory parameters, and arterial blood gases. Results: Thirty patients were included and equally randomized into the two groups. There were no significant differences in the length of ICU stay (mean difference, $\mathrm{MD}=-6.80 ; 95 \%$ $\mathrm{CI}=-18.71$ to 5.11 ) between the groups. Among the secondary outcomes, significant differences were observed in diaphragm thickness, fraction of inspired oxygen, partial pressure of oxygen/fraction of inspired oxygen ratio, C-reactive protein levels, lymphocyte count, and hemoglobin $(\mathrm{p}<0.05)$.

Conclusion: Among severe COVID-19 patients requiring invasive mechanical ventilation, the length of ICU stay was not significantly different between the PBMT-sMF and placebo groups. In contrast, PBMT-sMF was significantly associated with reduced diaphragm atrophy, improved ventilatory parameters and lymphocyte count, and decreased C-reactive protein levels and hemoglobin count.

Trial Registration Number (Clinical Trials.gov): NCT04386694.

Keywords: COVID-19, photobiomodulation, intensive care unit, respiratory muscles, ventilatory parameters, mechanical ventilation

\section{Introduction}

The novel coronavirus disease 2019 (COVID-19) is caused by severe acute respiratory syndrome coronavirus 2 (SARS-CoV-2). ${ }^{1}$ SARS-CoV-2 infection triggers hematological abnormalities such as leucopenia, lymphopenia, increased prothrombin time, increased D-dimer and C-reactive protein (CRP) levels, and increased cytokine levels such as interleukin (IL)-1 $\beta$ and tumor necrosis factor (TNF)- $\alpha^{2-4}$ The clinical features observed in COVID-19 patients mainly include fever, dry cough, and fatigue or myalgia ${ }^{2,5}$ and can range from no symptoms to severe pneumonia and even death. ${ }^{1}$ Severe cases usually 
progress to complications such as dyspnea, hypoxia, acute hypoxemic respiratory insufficiency, arrhythmia, acute cardiac injury, and shock, ${ }^{2,5,6}$ which often require critical care in the intensive care unit (ICU). ${ }^{2,5,7}$

To date, there has been no effective treatment for SARS-CoV-2 infection. Therefore, several therapeutic agents such as chloroquine, hydroxychloroquine, ${ }^{8}$ lopinavir-ritonavir, ${ }^{9}$ remdesivir, ${ }^{10}$ and dexamethasone ${ }^{11}$ have been tested and used in the attempt to treat COVID-19. Reports on the effectiveness of such therapeutic agents have been conflicting, ${ }^{8-10}$ and further high-quality randomized controlled trials are necessary to confirm whether the benefits outweigh the harm. However, given the lack of robust evidence regarding the effects of available therapeutic agents and the lack of effective treatment available to combat SARS-CoV-2, it is necessary to base management strategies on the signs and symptoms of COVID-19 patients, especially in the most severe cases. Respiratory management of severe COVID-19 ICU patients can be achieved through oxygen therapy, non-invasive ventilation, and intubation. ${ }^{12}$ Respiratory failure due to hypoxemia is one of the most prominent complications in these patients, ${ }^{13}$ and usually requires mechanical ventilation via an endotracheal tube. ${ }^{14}$ Acute respiratory failure reduces lung compliance, increases respiratory work, and affects blood oxygenation, leading to a shallow breathing pattern. ${ }^{15}$ The strength of respiratory muscles may also be reduced. ${ }^{16}$ The diaphragm is one of the respiratory muscles widely affected by critical illness and mechanical ventilation. $^{17,18}$ Prolonged diaphragm inactivity during mechanical ventilation is not only associated with changes in diaphragm thickness ${ }^{19}$ but also causes a rapid progression of diaphragm weakness. ${ }^{17,20}$ All these characteristics render the weaning of patients from mechanical ventilation difficult and increase the risk of ICU readmission, leading to a poorer clinical trajectory. ${ }^{21,22}$

Photobiomodulation therapy (PBMT) combined with static magnetic field (sMF) has the potential as a nonpharmacological intervention for the respiratory management of severe COVID-19 patients. PBMT is a non-thermal and non-ionizing light therapy applied in the form of light amplification by stimulated emission of radiation (LASER), lightemitting diodes (LEDs), and/or broad-band irradiation in the visible and infrared spectra. ${ }^{23}$ PBMT increases cellular metabolism, ${ }^{24,25}$ microcirculation, ${ }^{26}$ oxygen availability, ${ }^{27,28}$ and redox metabolism, ${ }^{29}$ as well as modulates inflammatory processes. ${ }^{30-32}$ Recently, PBMT has been used in combination with sMF. $^{31-34}$ sMF interacts with biological systems ${ }^{35}$ by increasing the production of adenosine triphosphate (ATP) and consequently enhancing cell metabolism. ${ }^{36}$ In addition, sMF reduces oxidative stress. ${ }^{37,38}$ Regardless of the exact mechanism of action, sMF has been shown to exert analgesic effects. $^{39-41}$ PBMT and SMF have been found to produce a synergistic effect by generating greater transfer of electrons. ${ }^{33,34,34-36,36-42,42,43}$ Robust evidence has shown that PBMT, isolated or in combination with SMF (PBMT-sMF), exerted beneficial effects on skeletal muscles, including increased physical performance, reduced fatigue, ${ }^{42,43}$ decreased performance loss and function during the detraining period, ${ }^{34}$ and increased oxygen saturation. ${ }^{27,28}$ In contrast, there is a lack of evidence on the effects of PBMT or PBMTsMF on respiratory muscles and the respiratory system in general. To date, only one clinical trial has evaluated the effects of PBMT on respiratory muscles and has shown its effectiveness in improving the functional capacity of chronic obstructive pulmonary disease patients. ${ }^{44}$ Furthermore, experimental studies on the respiratory system of animals have shown that PBMT can modulate pulmonary inflammation ${ }^{45-}$ 47 and relieve bronchial hyperresponsiveness. ${ }^{47}$

The previously reported beneficial effects coupled with the lack of known adverse effects suggest that PBMT-sMF may be a safer alternative to the pharmacological treatments of severe COVID-19 patients. However, it is unknown whether the effects of PBMT (or PBMT-sMF) on respiratory muscles are similar to those previously observed on skeletal muscles and whether PBMT-sMF can modulate inflammatory processes and contribute to the clinical improvement of these patients. Therefore, our study aimed to investigate the effects of PBMT-sMF on the length of ICU stay and mortality rate of severe COVID-19 patients requiring invasive mechanical ventilation, and assess its role in preventing respiratory muscle atrophy, increasing oxygen availability, modulating inflammatory process, and improving the general clinical outcomes of such patients.

\section{Patients and Methods}

\section{Trial Design}

A prospectively registered (NCT04386694), pragmatic, two-arm, parallel randomized, triple-blinded (patients, therapists, and outcome assessors), placebo-controlled trial was conducted. There were two deviations from the registered protocol. The first involved our estimation that the endpoint would be up to 20 days after randomization, with patients either discharged or dead from any cause within this period; however, as the study period directly 
depended on the length of ICU stay, it eventually extended beyond 20 days. The second deviation was regarding the failure to assess three secondary outcomes: immunoglobulin $\mathrm{G}(\mathrm{IgG})$, immunoglobulin $\mathrm{M}$ ( $\operatorname{IgM})$, and $\mathrm{D}$-dimer levels, as the laboratory in charge was unable to implement the necessary routines before beginning this trial. This study adhered to the CONSORT guidelines.

\section{Ethics}

This study was submitted and approved by the Research Ethics Committee of Associação Dr. Bartholomeu Tacchini/Hospital Tacchini/RS (protocol number: 3,985,226) and by the National Research Ethics Commission of the Brazilian Ministry of Health (protocol number: 4,021,485). This trial was performed in accordance with the Declaration of Helsinki and the Research Involving Human Subjects guidelines. All eligible patients or their legal representatives (if the patients were too unwell to provide consent) were informed of the study objectives and provided written informed consent before enrollment. All appropriate and customary steps were taken to ensure data security and patient confidentiality.

\section{Participants and Recruitment}

The participants were patients with laboratory-confirmed COVID-19 via the reverse transcription-polymerase chain reaction (RT-PCR) test, who were admitted to the adult ICU of the Hospital Tacchini, Bento Gonçalves, Brazil, between May 2020 and July 2020. The inclusion criteria included age $\geq 15$ years and the need for invasive mechanical ventilation through orotracheal intubation due to respiratory failure. The exclusion criteria included negative COVID-19 results, duration of prone position $>24$ hours, cancer patients, and pregnant women.

\section{Randomization and Blinding}

Prior to treatment initiation, the patients were randomized into two intervention groups: the active and placebo PBMT-sMF groups. Randomization was generated by a website (http://randomization.com/) and was performed by an independent researcher not involved in the recruitment, assessment, or treatment of the patients. The same researcher programmed the PBMT-sMF device to either the active or placebo mode according to the group allocations and was instructed not to disclose the programmed interventions to anyone involved in the study until its completion. The assessors, patients, and therapists were hence blinded throughout the treatment. Concealed allocation was achieved by the use of sequentially numbered, sealed, and opaque envelopes.

\section{Interventions}

All patients received standard ICU care in addition to the allocated PBMT-sMF treatment. Standard ICU care involved the administration of antibiotics, antivirals, corticoids, and sedatives. In addition, physical therapies such as bronchial hygiene techniques, passive mobilization exercises of the lower and upper limbs, pressure ulcer management (positional changes), bronchial secretion aspiration with a closed system, positive end-expiratory pressure (PEEP) titration, and passive sitting were implemented. The clinical evolution of the patients determined the progression of care. Active and placebo PBMT-sMF were performed using the same devices, with the same irradiated sites. To ensure blinding of the therapists, the devices emitted the same sounds and displayed the same information regardless of the programmed mode. Furthermore, since the amount of heat produced by the devices is undiscernible, ${ }^{33}$ blinding was not compromised by this aspect.

All patients underwent the allocated PBMT-sMF treatment once a day for seven days per week throughout their ICU stay (after study enrollment) until discharge or death, whichever came first. The intervention specifications were as follows:

1) Active PBMT-sMF: PBMT-sMF was performed using a cordless, portable MR5 Activ Pro LaserShowerTM device (PhotOxyl ${ }^{\mathrm{TM}}$ prototype, Multi Radiance Medical ${ }^{\mathrm{TM}}$, Solon, OH, USA) (Figure 1). A cluster probe with 20 diodes was used, which included 4 diodes of $905 \mathrm{~nm}$ (peak power: 50W, average mean optical output: 1.25 $\mathrm{mW}$, power density: $3.91 \mathrm{~mW} / \mathrm{cm}^{2}$, spot size: $0.32 \mathrm{~cm}^{2}$, and operating mode: superpulsed); 8 diodes of $633 \mathrm{~nm}$ (average optical output: $25 \mathrm{~mW}$, power density: 29.41 $\mathrm{mW} / \mathrm{cm}^{2}$, spot size: $0.85 \mathrm{~cm}^{2}$, and operating mode: pulsed); and 8 diodes of $850 \mathrm{~nm}$ (average optical output: $40 \mathrm{~mW}$, power density: $71.23 \mathrm{~mW} / \mathrm{cm}^{2}$, spot size: $0.56 \mathrm{~cm}^{2}$, and operating mode: pulsed). PBMT-sMF was applied to six sites $\left(33 \mathrm{~cm}^{2}\right.$ each site) of the lower thoracic/upper abdominal region and two sites $\left(33 \mathrm{~cm}^{2}\right.$ each site) of the neck area (sternocleidomastoid muscle), as illustrated in Figure 1. The exposure time was $60 \mathrm{~s}$ per site, yielding a total treatment time of $480 \mathrm{~s}$ ( $8 \mathrm{~min})$. The energy delivered per site was $31.50 \mathrm{~J}$, yielding a total delivered energy of $189 \mathrm{~J}$ and $63 \mathrm{~J}$ in the lower thoracic and neck regions, respectively. A total area of $264 \mathrm{~cm}^{2}$ 


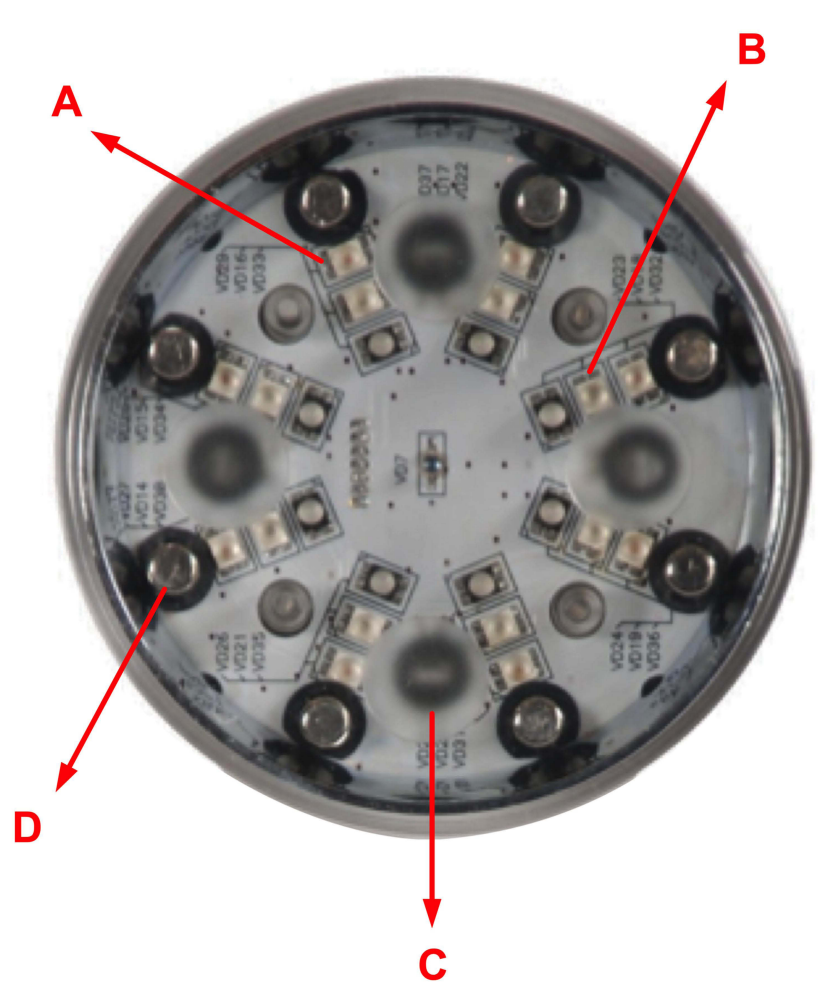

Figure I PBMT-sMF device. Figure I shows the device used to applied the PBMTsMF and placebo. A cluster probe with 20 diodes containing 4 diodes of $905 \mathrm{~nm}, 8$ diodes of $633 \mathrm{~nm}$ and 8 diodes of $850 \mathrm{~nm}$ was used: A - Red LEDs; B - Infrared LEDs; C - Super-pulsed laser; D - Magnetic field.

was irradiated with a dose of $0.95 \mathrm{~J} / \mathrm{cm}^{2}$. The energy delivered per site and the irradiation sites were established based on the previous study that applied PBMT to respiratory muscles. ${ }^{44}$ PBMT-sMF was applied using the direct contact method, with slight pressure on the skin. A full description of the intervention is presented in Figure 2.

2) Placebo PBMT-sMF: The same device was used without any emission of the therapeutic dose. In the placebo mode, the infrared laser diodes, infrared LED diodes, and SMF were deactivated. In addition, the mean power of each LED diode was decreased to $0.5 \mathrm{~mW}$ to maintain the visual aspect of the red light, while maintaining the energy delivered $(0.24 \mathrm{~J}$ per site $)$ and dose $\left(0.007 \mathrm{~J} / \mathrm{cm}^{2}\right)$ below therapeutic level. According to currently available evidence, the therapeutic windows of PBMT on small and large muscle groups are 20-60 J and 60-300 J, respectively. ${ }^{42,43}$ The irradiated sites and exposure time were kept the same as those in active PBMT-sMF treatment.

\section{Outcomes}

Demographic and clinical characteristics such as age, gender, comorbidities, disease severity, and health status before hospital admission measured using the Simplified Acute Physiology Score 3 (SAPS 3$)^{48}$ were collected from the electronic medical records. The primary and secondary outcomes were as follows:

\section{Primary Outcome}

- Length of ICU stay: The length of ICU stay was measured by the number of days of ICU admission from randomization to discharge or death from any cause.

\section{Secondary Outcomes}

- Survival rate: The survival rate was measured as the rate of those who survived and were discharged from the ICU against those who died during the study period.

- Diaphragm thickness: The diaphragm thickness was measured using ultrasound. ${ }^{48,49}$ The LOGIQe device (GE Healthcare, Chicago, USA) and a linear transducer (ML6-15 5-15 MHz, and 9L D - $8 \mathrm{MHz}$ ) were used. The measurements were performed with the patient in the supine position. The transducer was positioned in the zone of apposition between the anterior and midaxillary lines at the level of the ninth or tenth intercostal space. ${ }^{50}$ End-expiratory diaphragm thickness was measured in two consecutive breaths on two separate images. Measurements were repeated at least once until they were consistently within $10 \%$. The mean of all four measurements was used for analysis. ${ }^{50}$ Measurements were obtained at baseline (up to 24 hours after the initiation of invasive mechanical ventilation), 10 days after randomization (day 10), and within 24 hours of discharge or death from any cause (the endpoint).

- Blood parameters: C-reactive protein (CRP), TNF- $\alpha$, and vitamin $\mathrm{D}$ levels, and erythrocyte, hemoglobin, hematocrit, leucocyte, segmented neutrophil, eosinophil, basophil, lymphocyte, monocyte, and platelet counts were assessed at baseline (ICU admission), day 10, and the endpoint. All measured parameters were part of the daily routine blood tests performed at the hospital and were hence collected directly from the electronic medical records. The data were collected by two assessors who were blinded to the group allocations.

- Mechanical ventilation parameters: Positive endexpiratory pressure levels (PEEP) and fraction of inspired oxygen $\left(\mathrm{FiO}_{2}\right)$ were measured using a mechanical ventilator. The data were collected at baseline, day 10, and the endpoint. 
A

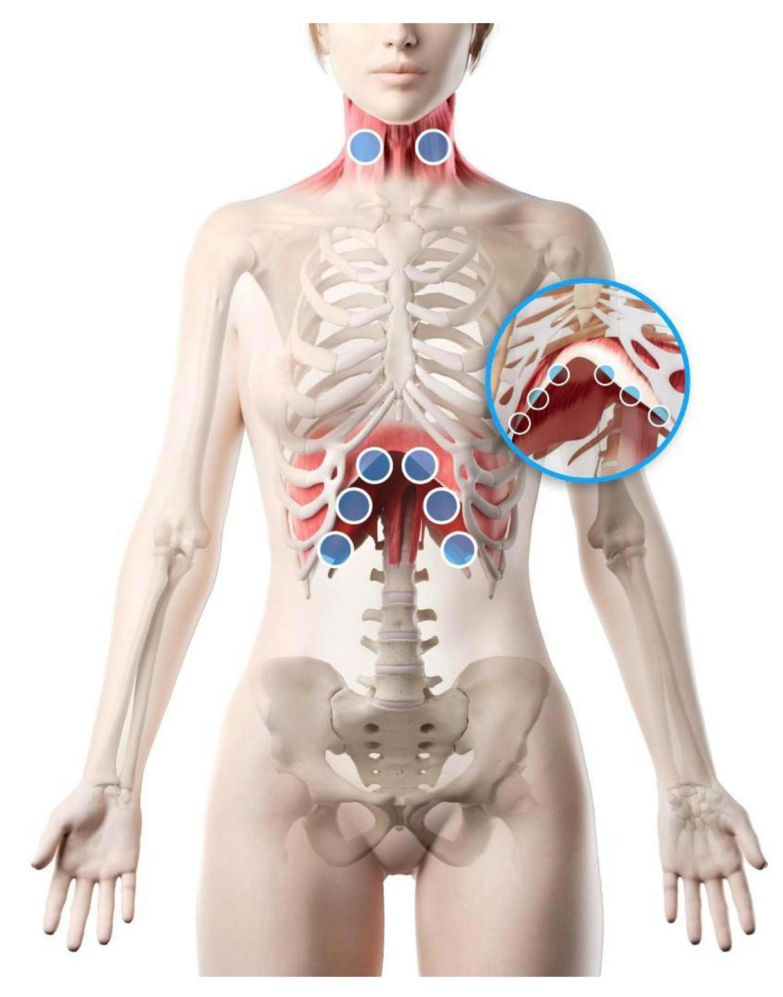

B

\begin{tabular}{|c|c|c|}
\hline & Diaphragm & Neck area \\
\hline Number of lasers & 4 & 4 \\
\hline Wavelength $(\mathrm{nm})$ & 905 & 905 \\
\hline Frequency $(\mathrm{Hz})$ & 250 & 250 \\
\hline Peak power $(W)$ - each & 50 & 50 \\
\hline $\begin{array}{l}\text { Average mean optical output }(\mathrm{mW}) \text { - } \\
\text { each }\end{array}$ & 1.25 & 1.25 \\
\hline Power density $\left(\mathrm{mW} / \mathrm{cm}^{2}\right)$ - each & 3.91 & 3.91 \\
\hline Energy density $\left(\mathrm{J} / \mathrm{cm}^{2}\right)$ - each & 0.234 & 0.234 \\
\hline Energy delivered $(\mathrm{J})$ - each & 0.075 & 0.075 \\
\hline Spot size of laser $\left(\mathrm{cm}^{2}\right)$ - each & 0.32 & 0.32 \\
\hline Number of red LEDs & 8 & 8 \\
\hline Wavelength of red LEDs $(\mathrm{nm})$ & 633 & 633 \\
\hline Frequency $(\mathrm{Hz})$ & 2 & 2 \\
\hline Average optical output (mW) - each & 25 & 25 \\
\hline Power density $\left(\mathrm{mW} / \mathrm{cm}^{2}\right)$ - each & 29.41 & 29.41 \\
\hline Energy density $\left(\mathrm{J} / \mathrm{cm}^{2}\right)$ - each & 1.765 & 1.765 \\
\hline Energy delivered $(\mathrm{J})$ - each & 1.50 & 1.50 \\
\hline Spot size of red LED $\left(\mathrm{cm}^{2}\right)$ - each & 0.85 & 0.85 \\
\hline Number of infrared LEDs & 8 & 8 \\
\hline Wavelength of infrared LEDs $(\mathrm{nm})$ & 850 & 850 \\
\hline Frequency $(\mathrm{Hz})$ & 250 & 250 \\
\hline Average optical output (mW) - each & 40 & 40 \\
\hline Power density $\left(\mathrm{mW} / \mathrm{cm}^{2}\right)$ - each & 71.23 & 71.23 \\
\hline Energy density $\left(\mathrm{J} / \mathrm{cm}^{2}\right)$ - each & 4.286 & 4.286 \\
\hline Energy delivered $(J)$ - each & 2.40 & 2.40 \\
\hline Spot size of infrared LED $\left(\mathrm{cm}^{2}\right)$ - each & 0.56 & 0.56 \\
\hline Magnetic field (mT) & 110 & 110 \\
\hline Irradiation time per site (sec) & 60 & 60 \\
\hline Total energy delivered per site $(\mathrm{J})$ & 31.50 & 31.50 \\
\hline Number of irradiated sites & 6 & 1 (bilaterally) \\
\hline $\begin{array}{l}\text { Total energy delivered to the muscle } \\
\text { group }(J)\end{array}$ & 189.00 & 31.50 (bilaterally) \\
\hline Aperture of device $\left(\mathrm{cm}^{2}\right)$ & 33 & 33 \\
\hline Dose $\left(\mathrm{J} / \mathrm{cm}^{2}\right)$ & 0.95 & 0.95 \\
\hline Application mode & $\begin{array}{l}\text { Cluster probe held } \\
\text { stationary in skin } \\
\text { contact with a } \\
\text { 90-degree angle } \\
\text { and slight pressure }\end{array}$ & $\begin{array}{l}\text { Cluster probe held } \\
\text { stationary in skin } \\
\text { contact with a } \\
\text { 90-degree angle } \\
\text { and slight pressure }\end{array}$ \\
\hline
\end{tabular}

Figure 2 Irradiation of interventions. (A) shows the sites where PBMT-sMF and placebo were irradiated. The interventions were irradiated at six sites in the lower thorax/ upper abdominal cavity and two sites in the neck area. (B) shows the full description of the parameters of PBMT-sMF applied in the treatment. This figure is owned by the authors.

- Arterial blood gases: The arterial partial pressure of oxygen $\left(\mathrm{PO}_{2}\right)$ and the $\mathrm{PO}_{2} / \mathrm{FiO}_{2}$ ratio were assessed at baseline, day 10 , and the endpoint. Both parameters were part of the routine blood tests performed by the hospital and were hence collected directly from the electronic medical records. The data were collected by two assessors who were blinded to the group allocation groups.

\section{Statistical Analysis}

To date, there are no published studies on the effects of PBMT-sMF in severe COVID-19 patients; thus, a convenience sample was used for this trial. To estimate our sample size, we considered the number of patients admitted to the ICU in the month before the start of our trial (April 2020) who met our inclusion and exclusion criteria $(n=10)$. By further estimating a 3-month enrollment period (after the randomization of the first patient), the convenience sample size was expected to reach 30 patients.
Statistical analysis was conducted following the intention-to-treat principle. ${ }^{51,52}$ Data normality was tested using the Kolmogorov-Smirnov test. Since the data were normally distributed, inter-group differences (treatment effects) were analyzed using the unpaired, two-tailed $t$ test (hospitalization data), and the two-way repeated measures analysis of variance (time vs experimental group) with post-hoc Bonferroni correction (ventilatory parameters, biochemical markers, and hemogram parameters). The association between categorical variables was analyzed using the Chi-square test. Data are expressed as mean, standard deviation (SD), mean difference (MD), and $95 \%$ confidence interval (CI). Data are expressed as frequency (\%). The significance level was defined as $\mathrm{p}<$ 0.05 . To evaluate practical significance, the magnitude of differences (Cohen's d) between groups was calculated using the means and SDs of the placebo and PBMT-sMF groups (using $\mathrm{G}^{*}$ Power 3.1 ). The following criteria of Cohen were adopted: small, 0.2; moderate, 0.50; and 
large, 0.80. All analyses were performed by an independent researcher who was not involved in data collection.

\section{Results}

\section{Patients}

Among the 62 patients who were assessed for eligibility, 30 were included and equally randomized into the placebo and PBMT-sMF groups ( $\mathrm{n}=15$ each). All patients received the allocated treatment (Figure 3 ). The mean age was 66.06 years, the mean height was $166.53 \mathrm{~cm}$, the mean body mass was $75.18 \mathrm{~kg}$, and $53.33 \%$ were male. The baseline demographic and clinical characteristics were similar between the groups $(\mathrm{p}>0.05)$, as shown in Table 1. No adverse effects were observed in either group.

\section{Primary Outcome}

The mean lengths of ICU stay of the placebo and PBMTsMF groups were 23.06 days and 16.26 days, respectively, with no significant differences observed $(\mathrm{MD}=-6.80$; $95 \% \mathrm{CI}=-18.71$ to 5.11 ) (Table 2 ).

\section{Secondary Outcomes}

There were no differences in diaphragm thickness at baseline $(\mathrm{p}=0.99 ; \mathrm{MD}=4.27 ; 95 \% \mathrm{CI}=-7.41$ to 15.95$)$; however, significantly increased diaphragm thickness was shown in the PBMT-sMF group at day $10(\mathrm{p}=0.0117$; MD $=14.19 ; 95 \% \mathrm{CI}=2.50$ to 25.87$)$ and the endpoint $(\mathrm{p}=$ $0.0001 ; \mathrm{MD}=20.46 ; 95 \% \mathrm{CI}=8.77$ to -32.14$)$ (Table 3 ). There were no differences in PEEP at baseline $(\mathrm{p}=0.99$; $\mathrm{MD}=-0.13 ; 95 \% \mathrm{CI}=-2.69$ to 2.43$)$, day $10(\mathrm{p}=$ $0.5540 ; \mathrm{MD}=-1.40 ; 95 \% \mathrm{CI}=-3.96$ to 1.16$)$, and the endpoint $(\mathrm{p}=0.3931 ; \mathrm{MD}=-1.60 ; 95 \% \mathrm{CI}=-4.16$ to 0.96 ) (Table 3 ). In addition, there were no differences in $\mathrm{PO}_{2}$ at baseline $(\mathrm{p}=0.99 ; \mathrm{MD}=16.76 ; 95 \% \mathrm{CI}=-8.64$ to $42.16)$, day $10(\mathrm{p}=0.99 ; \mathrm{MD}=6.72 ; 95 \% \mathrm{CI}=-18.68$ to 32.12 ), and the endpoint ( $\mathrm{p}=0.34 ; \mathrm{MD}=16.55 ; 95 \% \mathrm{CI}=$ -8.85 to 41.95 ) (Table 3 ). There were also no significant differences in $\mathrm{FiO}_{2}$ at baseline $(\mathrm{p}=0.33$; $\mathrm{MD}=-7.33$; $95 \% \mathrm{CI}=-30.92$ to 16.26$)$, and at day $10(\mathrm{p}=0.6590$; $\mathrm{MD}=-11.94 ; 95 \% \mathrm{CI}=-35.53$ to 11.65$)$; however, the PBMT-sMF group demonstrated significantly lower $\mathrm{FiO}_{2}$ at the endpoint $(\mathrm{p}=0.0456 ; \mathrm{MD}=-23.93 ; 95 \% \mathrm{CI}=$ -47.52 to -0.34 ) (Table 3 ). Finally, there were no difference in the $\mathrm{PO}_{2} / \mathrm{FiO}_{2}$ ratio at baseline $(\mathrm{p}=0.67 ; \mathrm{MD}=$ 52.94; $95 \% \mathrm{CI}=-53.63$ to 158.50$)$ and day $10(\mathrm{p}=$ $0.2246 ; \mathrm{MD}=77.95 ; 95 \% \mathrm{CI}=-27.63$ to 183.50$)$, but the PBMT-sMF group showed significantly higher $\mathrm{PO}_{2}$ $/ \mathrm{FiO}_{2}$ ratio at the endpoint $(\mathrm{p}=0.0233 ; \mathrm{MD}=117.90$; $95 \% \mathrm{CI}=12.31$ to 223.50$)$ (Table 3 ).

There were no differences in CRP levels at baseline ( $\mathrm{p}$ $=0.41 ; \mathrm{MD}=-49.01 ; 95 \% \mathrm{CI}=-131.60$ to 33.58$)$ and day $10(\mathrm{p}=0.99 ; \mathrm{MD}=-20.09 ; 95 \% \mathrm{CI}=-102.70$ to 62.50); however, the PBMT-sMF group showed significantly lower CRP levels ( $\mathrm{p}=0.045$; $\mathrm{MD}=-83.87 ; 95 \%$ $\mathrm{CI}=-166.50$ to -1.28 ) at the endpoint (Table 4). There were no differences in TNF- $\alpha$ levels at baseline $(\mathrm{p}=0.99$; $\mathrm{MD}=2.48 ; 95 \% \mathrm{CI}=-7.71$ to 12.68$)$, day $10(\mathrm{p}=0.44$; $\mathrm{MD}=6.11 ; 95 \% \mathrm{CI}=-4.08$ to 16.32$)$, and the endpoint ( $\mathrm{p}$ $=0.99 ; \mathrm{MD}=-2.87 ; 95 \% \mathrm{CI}=-13.07$ to 7.33 ) (Table 4).

There were no differences in vitamin $\mathrm{D}$ levels at baseline $(\mathrm{p}=0.43 ; \mathrm{MD}=4.15 ; 95 \% \mathrm{CI}=-2.75$ to 11.07$)$, day 10 $(\mathrm{p}=0.99 ; \mathrm{MD}=-0.42 ; 95 \% \mathrm{CI}=-7.34$ to 6.48$)$, and the endpoint $(\mathrm{p}=0.0502 ; \mathrm{MD}=6.90 ; 95 \% \mathrm{CI}=-0.004$ to 13.82) (Table 4). There was no differences in erythrocyte count at baseline $(\mathrm{p}=0.19 ; \mathrm{MD}=-0.45 ; 95 \% \mathrm{CI}=-1.02$ to 0.13$)$, day $10(\mathrm{p}=0.065 ; \mathrm{MD}=-0.55 ; 95 \% \mathrm{CI}=-1.13$ to 0.02 ), and the endpoint ( $\mathrm{p}=0.389 ; \mathrm{MD}=-0.36 ; 95 \%$ $\mathrm{CI}=-0.94$ to 0.21 ) (Table 4 ). There were no differences in hemoglobin count at baseline $(\mathrm{p}=0.29 ; \mathrm{MD}=-1.23 ; 95 \%$ $\mathrm{CI}=-3.03$ to 0.56$)$ and at the endpoint ( $\mathrm{p}=0.6173$; $\mathrm{MD}=$ $-0.94 ; 95 \% \mathrm{CI}=-2.74$ to 0.86 ), but the PBMT-sMF group showed significantly lower hemoglobin count $(\mathrm{p}=0.026$; $\mathrm{MD}=-1.97 ; 95 \% \mathrm{CI}=-3.77$ to -0.17 ) at day (Table 4$)$. There were no differences in hematocrit at baseline $(\mathrm{p}=$ $0.29 ; \mathrm{MD}=-3.25 ; 95 \% \mathrm{CI}=-7.98$ to 1.48$)$, at day $10(\mathrm{p}=$ $0.194 ; \mathrm{MD}=-3.62 ; 95 \% \mathrm{CI}=-8.36$ to 1.10$)$, and the endpoint $(\mathrm{p}=0.459 ; \mathrm{MD}=-2.79 ; 95 \% \mathrm{CI}=-7.52$ to 1.94) (Table 4). There were no differences in leukocytes count at baseline $(\mathrm{p}=0.99 ; \mathrm{MD}=709.30 ; 95 \% \mathrm{CI}=$ $-15,147$ to 16,566$)$, at day $10(\mathrm{p}=0.476$; $\mathrm{MD}=9227$; $95 \% \mathrm{CI}=-6629$ to 25,083$)$, and the endpoint ( $\mathrm{p}=0.99$; $\mathrm{MD}=5444 ; 95 \% \mathrm{CI}=-10,412$ to 21,300 ) (Table 4 ). There were no differences in segmented neutrophil count at baseline ( $\mathrm{p}=0.99 ; \mathrm{MD}=-56.02 ; 95 \% \mathrm{CI}=-6836$ to 6724), day $10(\mathrm{p}=0.91 ; \mathrm{MD}=-2856 ; 95 \% \mathrm{CI}=-9636$ to $3924)$, and the endpoint ( $\mathrm{p}=0.99 ; \mathrm{MD}=1362 ; 95 \% \mathrm{CI}=$ -5418 to 8142 ) (Table 4). There were no differences in eosinophil count at baseline $(\mathrm{p}=0.99 ; \mathrm{MD}=2.30 ; 95 \% \mathrm{CI}$ $=-1032$ to 1037$)$, day $10(\mathrm{p}=0.99 ; \mathrm{MD}=95.70 ; 95 \% \mathrm{CI}$ $=-939$ to 1130$)$, and the endpoint $(\mathrm{p}=0.146 ; \mathrm{MD}=$ $-846.40 ; 95 \% \mathrm{CI}=-1881$ to 188.3 ) (Table 4 ). There were no differences in basophil count at baseline ( $\mathrm{p}=$ $0.99 ; \mathrm{MD}=1.73 ; 95 \% \mathrm{CI}=-15.79$ to 19.26$)$, day $10(\mathrm{p}$ $=0.99 ; \mathrm{MD}=2.93 ; 95 \% \mathrm{CI}=-14.59$ to 20.46$)$, and the 


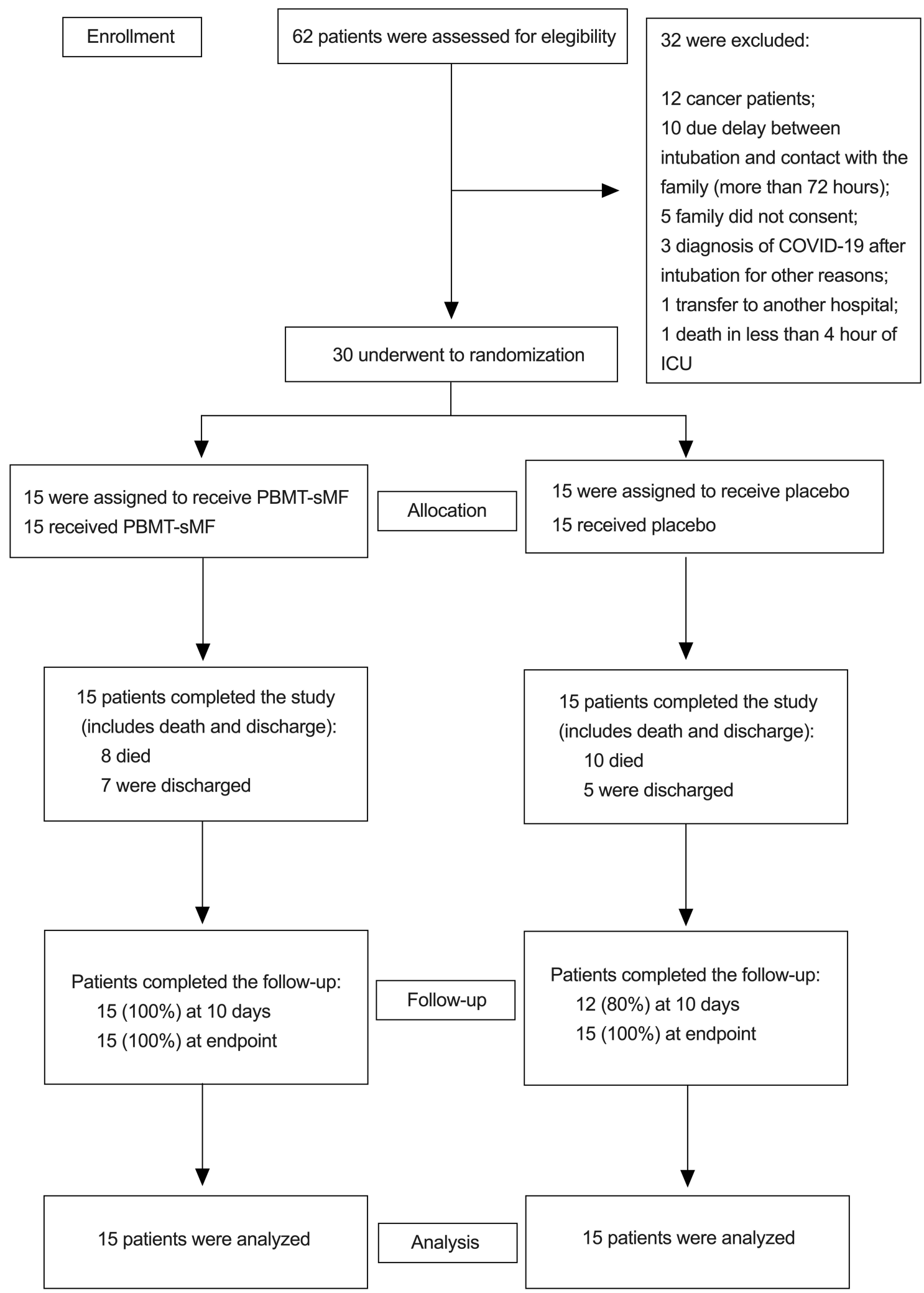

Figure 3 CONSORT flow diagram of the study. Figure 3 shows the flow diagram of the study including enrollment, randomization, intervention allocation, follow-up and data analysis of the two groups. 
Table I Demographic and Clinical Characteristics of the Patients at Baseline

\begin{tabular}{|c|c|c|c|}
\hline & $\begin{array}{l}\text { Placebo } \\
(n=15)\end{array}$ & $\begin{array}{l}\text { PBMT-sMF } \\
(n=15)\end{array}$ & P value \\
\hline Age (years) & 67.93 (II.68) & $64.2(18.67)$ & 0.51 \\
\hline \multicolumn{4}{|l|}{ Gender (\%) } \\
\hline Female & 8 & 6 & \\
\hline Male & 6 & 8 & \\
\hline Body mass $(\mathrm{Kg})$ & 77.96 (18.49) & $72.40(16.94)$ & 0.39 \\
\hline Height (cm) & $165.06(11.57)$ & $168(7.98)$ & 0.42 \\
\hline SPAS 3 & $63.40(13.43)$ & $59.73(13.24)$ & 0.46 \\
\hline \multicolumn{4}{|l|}{ Comorbidities (\%) } \\
\hline Hypertension & $9(60.0)$ & $5(33.3)$ & \\
\hline Diabetes & $8(53.3)$ & $4(26.7)$ & \\
\hline Obesity & $4(26.7)$ & $3(20.0)$ & \\
\hline Dementia & $3(20.0)$ & $2(13.3)$ & \\
\hline Depression & $2(13.3)$ & $0(0.00)$ & \\
\hline
\end{tabular}

Notes: Categorical variables are expressed as number (\%). Continuous variables are expressed as mean (SD).

Abbreviations: PBMT-sMF, photobiomodulation therapy combined with static magnetic field; SAPS 3, Simplified Acute Physiology Score 3.

endpoint $(\mathrm{p}=0.99 ; \mathrm{MD}=4.33 ; 95 \% \mathrm{CI}=-13.19$ to 21.86) (Table 4). There were no differences in lymphocyte count at baseline $(\mathrm{p}=0.87 ; \mathrm{MD}=418.9 ; 95 \% \mathrm{CI}=-543$ to 1381$)$ and day $10(\mathrm{p}=0.99 ; \mathrm{MD}=170.8 ; 95 \% \mathrm{CI}=$ -791.1 to 1133 ), while the PBMT-sMF group showed significantly higher lymphocyte count at the endpoint (p $=0.0125 ; \mathrm{MD}=1160.00 ; 95 \% \mathrm{CI}=197.90$ to 2122.00 ) (Table 4). There were no differences in monocytes count at baseline $(\mathrm{p}=0.99 ; \mathrm{MD}=104.2 ; 95 \% \mathrm{CI}=-431.3$ to 639.6), day $10(\mathrm{p}=0.576 ; \mathrm{MD}=288.2 ; 95 \% \mathrm{CI}=-247.2$ to 823.6$)$, and the endpoint ( $\mathrm{p}=0.571 ; \mathrm{MD}=289.2 ; 95 \%$ $\mathrm{CI}=-246.2$ to 824.6 ) (Table 4). There were no differences in platelet count at baseline $(\mathrm{p}=0.99 ; \mathrm{MD}=20,228 ; 95 \%$ $\mathrm{CI}=-83,748$ to 124,204$)$, day $10(\mathrm{p}=0.99 ; \mathrm{MD}=23,967$; $95 \% \mathrm{CI}=-80,009$ to 127,943$)$, and the endpoint ( $\mathrm{p}=0.54$; $\mathrm{MD}=57,533 ; 95 \% \mathrm{CI}=-46,443$ to 161,509 ) (Table 4 ).

\section{Sample Size Calculation for Future Randomized Controlled Trials}

Based on the results of our primary outcome, we were able to determine the sample size required for future studies investigating the effects of PBMT-sMF in COVID-19 ICU patients requiring invasive mechanical ventilation.

The lengths of ICU stay of the placebo and PBMT-sMF groups were $23.06 \pm 20.37$ days and $16.26 \pm 9.61$ days, respectively. By considering a $\beta$-value of $20 \%$ and an $\alpha$ value of $5 \%$, the required sample size was 68 patients per group. This was calculated using the $\mathrm{SPH}^{\mathrm{TM}}$ Analytics website (https://www.sphanalytics.com/sample-sizecalculator-using-average-values/).

Table 2 Hospitalization Outcomes

\begin{tabular}{|c|c|c|c|c|c|}
\hline & Placebo & PBMT-sMF & $\begin{array}{c}\text { Between Groups } \\
\text { Comparisons }\end{array}$ & $\begin{array}{c}\text { Mean Difference } \\
{[95 \% \mathrm{Cl}]}\end{array}$ & $\begin{array}{l}\text { Effect Size } \\
\text { Cohen d }\end{array}$ \\
\hline $\begin{array}{l}\text { Length of stay in } \\
\text { ICU (Days) }\end{array}$ & $\begin{array}{c}\text { Total }(n=15): 23.06( \pm \\
20.37) \\
\text { Non-survivors }(n=10) \text { : } \\
20.4( \pm 20.58) \\
\text { Survivors }(n=5): 28.4( \pm \\
21.12)\end{array}$ & $\begin{array}{c}\text { Total }(n=15): 16.26( \pm \\
9.61) \\
\text { Non-survivors }(n=8) \text { : } \\
\text { I8.65 }( \pm 9.88) \\
\text { Survivors }(n=7): \text { I } 3.57( \pm \\
9.25)\end{array}$ & $\begin{array}{c}\text { Total: } p=0.25 \\
\text { Non-survivors: } p=0.82 \\
\text { Survivors: } p=0.12\end{array}$ & $\begin{array}{c}\text { Total: }-6.80 \\
\text { [-I8.7I to } 5.1 \mathrm{I}] \\
\text { Non-survivors: } \\
\quad-1.75 \\
\text { [-18.6 to } 15.1] \\
\text { Survivors: }-14.83 \\
\text { [-34.6I to } 4.94]\end{array}$ & $\begin{array}{l}\text { Total: } 0.4 \text { (small) } \\
\text { Non-survivors: } \\
0.1 \text { (small) } \\
\text { Survivors: } 0.9 \\
\text { (large) }\end{array}$ \\
\hline $\begin{array}{l}\text { Hospitalization } \\
\text { length (Days) }\end{array}$ & $\begin{array}{c}\text { Total }(n=15): 24.33( \pm \\
20.24) \\
\text { Non-survivors }(n=10) \text { : } \\
20.40( \pm 20.58) \\
\text { Survivors }(n=5): 32.20( \pm \\
19.09)\end{array}$ & $\begin{array}{c}\text { Total }(n=15): 18.33( \pm \\
8.95) \\
\text { Non-survivors }(n=8) \text { : } \\
18.75( \pm 10.08) \\
\text { Survivors }(n=7): 17.85( \pm \\
8.17)\end{array}$ & $\begin{array}{c}\text { Total: } p=0.30 \\
\text { Non-survivors: } p=0.83 \\
\text { Survivors: } p=0.10\end{array}$ & $\begin{array}{c}\text { Total: }-6.0 \\
\text { [-17.7 to } 5.69] \\
\text { Non-survivors: } \\
-1.65 \\
\text { [-18.56 to } 15.26] \\
\text { Survivors: }-14.35 \\
\text { [-32.13 to } 3.43]\end{array}$ & $\begin{array}{c}\text { Total: } 0.4 \text { (small) } \\
\text { Non-survivors: } \\
0.1 \text { (small) } \\
\text { Survivors: } 0.9 \\
\text { (large) }\end{array}$ \\
\hline Deaths/Discharges & $10 / 5$ & $8 / 7$ & $p=0.46$ & $\longrightarrow$ & $\longrightarrow$ \\
\hline
\end{tabular}

Notes: Continuous variables are expressed as mean (standard deviation). Categorical variables are expressed as number.

Abbreviations: PBMT-sMF, photobiomodulation therapy combined with static magnetic field; $\mathrm{ICU}$, intensive care unit; $\mathrm{Cl}$, confidence interval. 


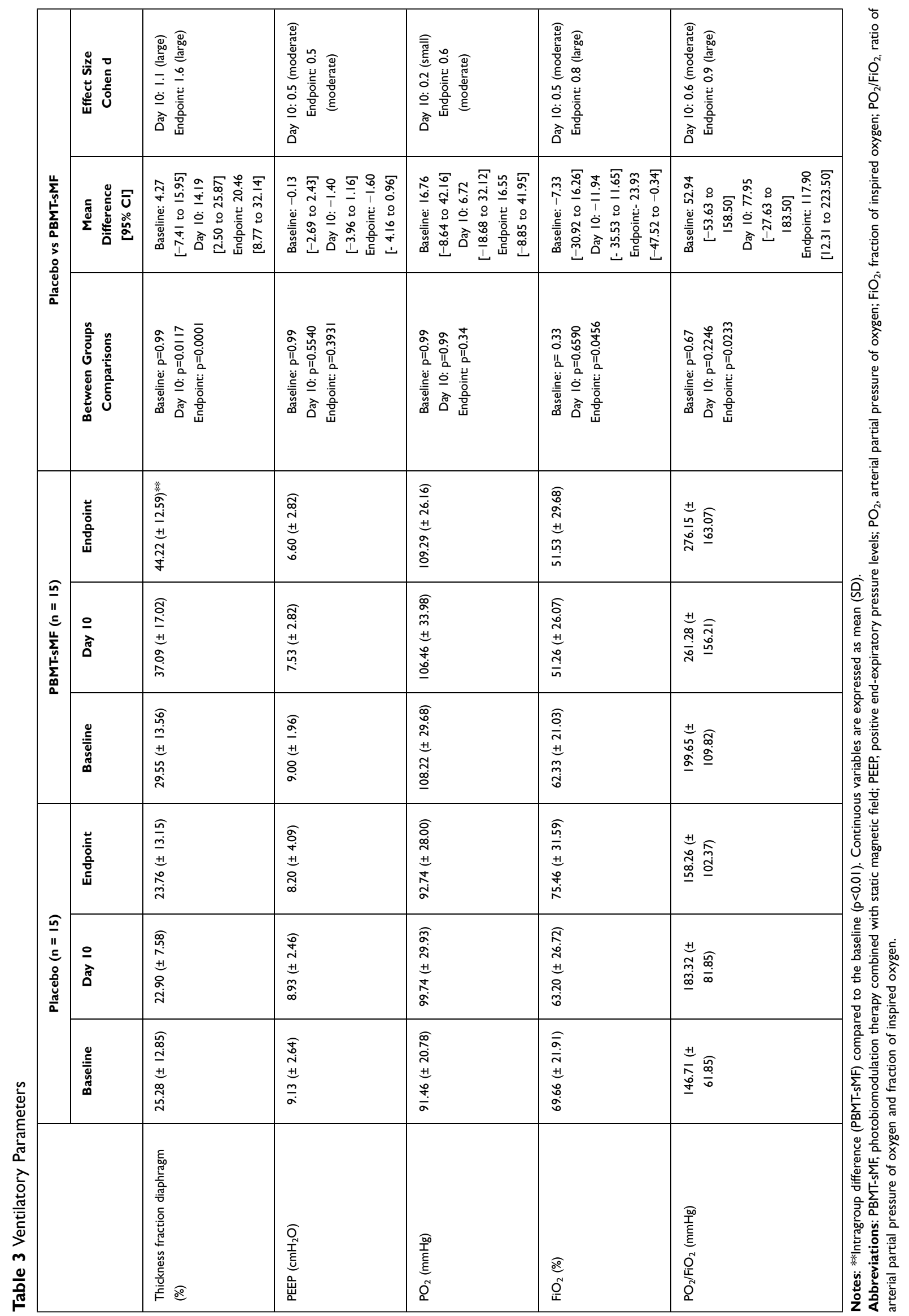


Table 4 Biochemical Markers and Hemogram Parameters

\begin{tabular}{|c|c|c|c|c|c|c|c|c|c|}
\hline & \multicolumn{3}{|c|}{ Placebo $(n=15)$} & \multicolumn{3}{|c|}{ PBMT-sMF $(n=15)$} & \multirow[b]{2}{*}{$\begin{array}{c}\text { Between } \\
\text { Groups } \\
\text { Comparisons }\end{array}$} & \multirow[b]{2}{*}{$\begin{array}{c}\text { Mean } \\
\text { Difference } \\
{[95 \% \mathrm{Cl}]}\end{array}$} & \multirow[b]{2}{*}{$\begin{array}{c}\text { Effect Size } \\
\text { Cohen d }\end{array}$} \\
\hline & Baseline & Day 10 & Endpoint & Baseline & Day 10 & Endpoint & & & \\
\hline CRP $(\mathrm{mg} / \mathrm{dL})$ & $\begin{array}{c}201.30( \pm \\
65.39)\end{array}$ & $\begin{array}{c}118.79( \pm \\
71.00)\end{array}$ & $\begin{array}{c}156.53( \pm \\
\text { I24.49) }\end{array}$ & $\begin{array}{c}152.29( \pm \\
108.88)\end{array}$ & $\begin{array}{c}98.70( \pm \\
95.24)\end{array}$ & $\begin{array}{c}72.66( \pm \\
75.40)\end{array}$ & $\begin{array}{c}\text { Baseline: } p=0.41 \\
\text { Day 10: } p=0.99 \\
\text { Endpoint: } \\
\quad p=0.045\end{array}$ & $\begin{array}{c}\text { Baseline: - } \\
49.01 \\
\text { [-131.60 to } \\
33.58] \\
\text { Day 10: } \\
-20.09 \\
{[-102.70 \text { to }} \\
62.50] \\
\text { Endpoint: } \\
-83.87 \\
{[-166.50 \text { to }} \\
-1.28]\end{array}$ & $\begin{array}{c}\text { Day 10: } 0.2 \\
\quad \text { (small) } \\
\text { Endpoint: } 0.8 \\
\quad \text { (large) }\end{array}$ \\
\hline $\begin{array}{l}\text { TNF-alpha (pg/ } \\
\mathrm{mL})\end{array}$ & $\begin{array}{c}17.23( \pm \\
13.46)\end{array}$ & $\begin{array}{c}12.28( \pm \\
5.42)\end{array}$ & $\begin{array}{c}17.05( \pm \\
7.54)\end{array}$ & $\begin{array}{c}19.71( \pm \\
17.51)\end{array}$ & $\begin{array}{c}18.40( \pm \\
13.43)\end{array}$ & $\begin{array}{c}14.19( \pm \\
5.44)\end{array}$ & $\begin{array}{l}\text { Baseline: } p=0.99 \\
\text { Day 10: } p=0.44 \\
\text { Endpoint: } p=0.99\end{array}$ & $\begin{array}{c}\text { Baseline: } 2.48 \\
\text { [-7.7| to } \\
\text { |2.68] } \\
\text { Day 10: } 6.11 \\
\text { [-4.08 to } \\
\text { 16.32] } \\
\text { Endpoint: - } \\
2.87 \\
\text { [-|3.07 to } \\
7.33]\end{array}$ & $\begin{array}{c}\text { Day 10: } 0.5 \\
\text { (moderate) } \\
\text { Endpoint:0.4 } \\
\text { (small) }\end{array}$ \\
\hline $\begin{array}{l}\text { Vitamin D (ng/ } \\
\mathrm{mL})\end{array}$ & $\begin{array}{c}14.88( \pm \\
5.13)\end{array}$ & $\begin{array}{c}18.28( \pm \\
9.95)\end{array}$ & $\begin{array}{c}14.16( \pm \\
4.80)\end{array}$ & $\begin{array}{c}19.04( \pm \\
10.83)\end{array}$ & $\begin{array}{c}17.85( \pm \\
6.67)\end{array}$ & $\begin{array}{c}21.07( \pm \\
7.07)\end{array}$ & $\begin{array}{c}\text { Baseline: } p=0.43 \\
\text { Day 10: } p=0.99 \\
\text { Endpoint: } \\
\quad p=0.0502\end{array}$ & $\begin{array}{c}\text { Baseline: } 4.15 \\
\text { [-2.75 to } \\
\text { II.07] } \\
\text { Day 10: }-0.42 \\
\text { [-7.34 to } \\
6.48] \\
\text { Endpoint: } 6.90 \\
\text { [-0.004 to } \\
\text { 13.82] }\end{array}$ & $\begin{array}{c}\text { Day 10: } 0.1 \\
\quad \text { (small) } \\
\text { Endpoint: I.I } \\
\quad \text { (large) }\end{array}$ \\
\hline $\begin{array}{l}\text { Erythrocytes } \\
\text { (millions } / \mathrm{mm}^{3} \text { ) }\end{array}$ & $\begin{array}{c}4.20( \pm \\
0.58)\end{array}$ & $\begin{array}{c}3.73( \pm \\
0.55)\end{array}$ & $\begin{array}{l}3.40( \pm \\
0.54)^{\# \#}\end{array}$ & $\begin{array}{c}3.75 \\
( \pm 0.64)\end{array}$ & $\begin{array}{c}3.18( \pm \\
0.59)\end{array}$ & $\begin{array}{l}3.04( \pm \\
0.90) * *\end{array}$ & $\begin{array}{c}\text { Baseline: } p=0.19 \\
\text { Day I0: } p=0.065 \\
\text { Endpoint: } \\
p=0.389\end{array}$ & $\begin{array}{c}\text { Baseline: } \\
-0.45 \\
\text { [-1.02 to } \\
0.13] \\
\text { Day 10: }-0.55 \\
\text { [-1.13 to } \\
0.02] \\
\text { Endpoint: } \\
-0.36 \\
\text { [-0.94 to } \\
0.21]\end{array}$ & $\begin{array}{l}\text { Day 10: } 0.9 \\
\quad \text { (large) } \\
\text { Endpoint: } 0.5 \\
\text { (moderate) }\end{array}$ \\
\hline
\end{tabular}

(Continued) 
Table 4 (Continued).

\begin{tabular}{|c|c|c|c|c|c|c|c|c|c|}
\hline & \multicolumn{3}{|c|}{ Placebo $(n=15)$} & \multicolumn{3}{|c|}{ PBMT-sMF $(n=15)$} & \multirow[b]{2}{*}{$\begin{array}{c}\text { Between } \\
\text { Groups } \\
\text { Comparisons }\end{array}$} & \multirow[b]{2}{*}{$\begin{array}{c}\text { Mean } \\
\text { Difference } \\
{[95 \% \mathrm{Cl}]}\end{array}$} & \multirow[b]{2}{*}{$\begin{array}{c}\text { Effect Size } \\
\text { Cohen d }\end{array}$} \\
\hline & Baseline & Day 10 & Endpoint & Baseline & Day 10 & Endpoint & & & \\
\hline $\begin{array}{l}\text { Haemoglobin } \\
(\mathrm{g} / \mathrm{dL})\end{array}$ & $\begin{array}{c}12.57( \pm \\
1.91)\end{array}$ & $\begin{array}{c}11.47( \pm \\
1.78)\end{array}$ & $\begin{array}{l}9.97( \pm \\
1.73)^{\# \#}\end{array}$ & $\begin{array}{c}11.34( \pm \\
2.14)\end{array}$ & $\begin{array}{l}9.50( \pm \\
1.55)^{*}\end{array}$ & $\begin{array}{l}9.03( \pm \\
2.75)^{* *}\end{array}$ & $\begin{array}{c}\text { Baseline: } p=0.29 \\
\text { Day I0: } p=0.026 \\
\text { Endpoint: } \\
\quad p=0.6173\end{array}$ & $\begin{array}{c}\text { Baseline: } \\
-1.23 \\
\text { [-3.03 to } \\
0.56] \\
\text { Day 10: }-1.97 \\
\text { [-3.77 to } \\
-0.17] \\
\text { Endpoint: } \\
-0.94 \\
\text { [-2.74 to } \\
0.86]\end{array}$ & $\begin{array}{c}\text { Day 10: } 1.2 \\
\quad \text { (large) } \\
\text { Endpoint: } 0.4 \\
\text { (small) }\end{array}$ \\
\hline Hematocrit (\%) & $\begin{array}{c}36.92( \pm \\
4.94)\end{array}$ & $\begin{array}{c}32.66( \pm \\
5.46)\end{array}$ & $\begin{array}{c}30.57( \pm \\
4.58)^{\# \#}\end{array}$ & $\begin{array}{c}33.67( \pm \\
5.04)\end{array}$ & $\begin{array}{c}29.03( \pm \\
4.04)\end{array}$ & $\begin{array}{c}27.78( \pm \\
7.20)^{* *}\end{array}$ & $\begin{array}{c}\text { Baseline: } p=0.29 \\
\text { Day I0: } p=0.194 \\
\text { Endpoint: } \\
\quad p=0.459\end{array}$ & $\begin{array}{c}\text { Baseline: } \\
-3.25 \\
\text { [-7.98 to } \\
\text { I.48] } \\
\text { Day 10: }-3.62 \\
\text { [-8.36 to } \\
\text { I.10] } \\
\text { Endpoint: } \\
-2.79 \\
\text { [-7.52 to } \\
1.94]\end{array}$ & $\begin{array}{l}\text { Day 10: } 0.8 \\
\quad \text { (large) } \\
\text { Endpoint: } 0.5 \\
\text { (moderate) }\end{array}$ \\
\hline $\begin{array}{l}\text { Leukocytes } \\
\left(\mathrm{mm}^{3}\right)\end{array}$ & $\begin{array}{c}1 \mathrm{I}, 466.00 \\
( \pm 6677.06)\end{array}$ & $\begin{array}{c}\mid 4,221.92 \\
( \pm 523 \mid .44)\end{array}$ & $\begin{array}{c}17,742.66 \\
( \pm \\
11,630.20)\end{array}$ & $\begin{array}{c}12,175.33 \\
( \pm 9330.37)\end{array}$ & $\begin{array}{c}23,449.13 \\
( \pm \\
33,682.68)\end{array}$ & $\begin{array}{c}23,186.66 \\
( \pm \\
21,612.65)\end{array}$ & $\begin{array}{l}\text { Baseline: } p=0.99 \\
\text { Day 10: } p=0.476 \\
\text { Endpoint: } p=0.99\end{array}$ & $\begin{array}{c}\text { Baseline: } \\
709.30 \\
\text { [-15,147 to } \\
\text { 16,566] } \\
\text { Day 10: } 9227 \\
\text { [-6629 to } \\
25,083] \\
\text { Endpoint: } \\
5444 \\
{[-10,412 \text { to }} \\
21,300]\end{array}$ & $\begin{array}{l}\text { Day 10: } 0.4 \\
\quad \text { (small) } \\
\text { Endpoint: } 0.3 \\
\quad \text { (small) }\end{array}$ \\
\hline $\begin{array}{l}\text { Segmented } \\
\text { Neutrals }\left(\mathrm{mm}^{3}\right)\end{array}$ & $\begin{array}{c}9890.16( \pm \\
5904.32)\end{array}$ & $\begin{array}{c}13,010.82 \\
( \pm 3191.26)\end{array}$ & $\begin{array}{c}13,655.49 \\
( \pm \\
10,037.05)\end{array}$ & $\begin{array}{c}9834.14( \pm \\
7425.83)\end{array}$ & $\begin{array}{c}10,154.81 \\
( \pm 3450.12)\end{array}$ & $\begin{array}{c}15,017.58 \\
( \pm \\
11,566.73)\end{array}$ & $\begin{array}{l}\text { Baseline: } p=0.99 \\
\text { Day I0: } p=0.91 \\
\text { Endpoint: } p=0.99\end{array}$ & $\begin{array}{c}\text { Baseline: } \\
-56.02 \\
\text { [-6836 to } \\
6724] \\
\text { Day 10: } \\
-2856 \\
\text { [-9636 to } \\
3924] \\
\text { Endpoint: } \\
\text { 1362 } \\
\text { [-5418 to } \\
8142]\end{array}$ & $\begin{array}{l}\text { Day 10: } 0.9 \\
\quad \text { (large) } \\
\text { Endpoint: } 0.1 \\
\text { (small) }\end{array}$ \\
\hline
\end{tabular}

(Continued) 
Table 4 (Continued).

\begin{tabular}{|c|c|c|c|c|c|c|c|c|c|}
\hline & \multicolumn{3}{|c|}{ Placebo $(n=15)$} & \multicolumn{3}{|c|}{ PBMT-sMF $(n=15)$} & \multirow[b]{2}{*}{$\begin{array}{c}\text { Between } \\
\text { Groups } \\
\text { Comparisons }\end{array}$} & \multirow[b]{2}{*}{$\begin{array}{c}\text { Mean } \\
\text { Difference } \\
{[95 \% \mathrm{Cl}]}\end{array}$} & \multirow[b]{2}{*}{$\begin{array}{c}\text { Effect Size } \\
\text { Cohen d }\end{array}$} \\
\hline & Baseline & Day 10 & Endpoint & Baseline & Day 10 & Endpoint & & & \\
\hline $\begin{array}{l}\text { Eosinophiles } \\
\left(\mathrm{mm}^{3}\right)\end{array}$ & $\begin{array}{c}47.43( \pm \\
90.35)\end{array}$ & $\begin{array}{c}19.41( \pm \\
29.58)\end{array}$ & $\begin{array}{l}1070.21( \pm \\
2825.97)^{\#}\end{array}$ & $\begin{array}{c}49.73( \pm \\
108.99)\end{array}$ & $\begin{array}{l}\text { II5.II ( } \\
\text { I14.62) }\end{array}$ & $\begin{array}{c}223.86( \pm \\
229.56)\end{array}$ & $\begin{array}{c}\text { Baseline: } p=0.99 \\
\text { Day I0: } p=0.99 \\
\text { Endpoint: } \\
\quad p=0.146\end{array}$ & $\begin{array}{c}\text { Baseline: } 2.30 \\
\text { [-1032 to } \\
\text { 1037] } \\
\text { Day 10: } 95.70 \\
\text { [-939 to } \\
\text { |130] } \\
\text { Endpoint: } \\
-846.40 \\
\text { [-188| to } \\
\text { |88.3] }\end{array}$ & $\begin{array}{l}\text { Day 10: I.I } \\
\quad \text { (large) } \\
\text { Endpoint: } 0.4 \\
\quad \text { (small) }\end{array}$ \\
\hline Basophils $\left(\mathrm{mm}^{3}\right)$ & $\begin{array}{c}5.84( \pm \\
6.07)\end{array}$ & $\begin{array}{l}7.83( \pm \\
11.16)\end{array}$ & $\begin{array}{c}18.54( \pm \\
27.53)\end{array}$ & $\begin{array}{l}7.57( \pm \\
11.23)\end{array}$ & $\begin{array}{c}10.77( \pm \\
18.75)\end{array}$ & $\begin{array}{c}22.88( \pm \\
30.30)\end{array}$ & $\begin{array}{l}\text { Baseline: } p=0.99 \\
\text { Day 10: } p=0.99 \\
\text { Endpoint: } p=0.99\end{array}$ & $\begin{array}{c}\text { Baseline: } 1.73 \\
\text { [-15.79 to } \\
\text { 19.26] } \\
\text { Day 10: } 2.93 \\
\text { [-14.59 to } \\
20.46] \\
\text { Endpoint: } 4.33 \\
\text { [-13.19 to } \\
21.86]\end{array}$ & $\begin{array}{c}\text { Day 10: } 0.2 \\
\quad \text { (small) } \\
\text { Endpoint: } 0.2 \\
\quad \text { (small) }\end{array}$ \\
\hline $\begin{array}{l}\text { Lymphocyte } \\
\left(\mathrm{mm}^{3}\right)\end{array}$ & $\begin{array}{c}764.31( \pm \\
415.39)\end{array}$ & $\begin{array}{c}1138.70( \pm \\
484.81)\end{array}$ & $\begin{array}{c}1554.00( \pm \\
1072.52)\end{array}$ & $\begin{array}{c}1183.26 \\
( \pm \mid 224.40)\end{array}$ & $\begin{array}{c}1309.53( \pm \\
560.02)\end{array}$ & $\begin{array}{c}27 \mid 3.83( \pm \\
1899.26)^{* *}, \\
\$ *\end{array}$ & $\begin{array}{c}\text { Baseline: } p=0.87 \\
\text { Day 10: } p=0.99 \\
\text { Endpoint: } \\
p=0.0125\end{array}$ & $\begin{array}{c}\text { Baseline: } \\
4 \mid 8.9 \\
\text { [-543 to } \\
\text { |38|] } \\
\text { Day 10: I70.8 } \\
\text { [-79|.| to } \\
\text { ||33] } \\
\text { Endpoint: } \\
\text { || } 60.00 \\
\text { [197.90 to } \\
2 \mid 22.00]\end{array}$ & $\begin{array}{c}\text { Day 10: } 0.3 \\
\quad \text { (small) } \\
\text { Endpoint: } 0.8 \\
\quad \text { (large) }\end{array}$ \\
\hline $\begin{array}{l}\text { Monocytes } \\
\left(\mathrm{mm}^{3}\right)\end{array}$ & $\begin{array}{c}557.06( \pm \\
459.19)\end{array}$ & $\begin{array}{c}936.71( \pm \\
499.14)\end{array}$ & $\begin{array}{c}1057.01( \pm \\
646.43)\end{array}$ & $\begin{array}{c}661.23( \pm \\
542.04)\end{array}$ & $\begin{array}{c}1224.89( \pm \\
496.07)^{*}\end{array}$ & $\begin{array}{l}1346.20( \pm \\
862.56)^{* *}\end{array}$ & $\begin{array}{c}\text { Baseline: } p=0.99 \\
\text { Day 10: } p=0.576 \\
\text { Endpoint: } \\
p=0.571\end{array}$ & $\begin{array}{c}\text { Baseline: } \\
\text { 104.2 } \\
\text { [-431.3 to } \\
639.6] \\
\text { Day 10: } 288.2 \\
\text { [-247.2 to } \\
823.6] \\
\text { Endpoint: } \\
289.2 \\
\text { [-246.2 to } \\
824.6]\end{array}$ & $\begin{array}{c}\text { Day 10: } 0.6 \\
\text { (moderate) } \\
\text { Endpoint: } 0.4 \\
\quad \text { (small) }\end{array}$ \\
\hline
\end{tabular}

(Continued) 
Table 4 (Continued).

\begin{tabular}{|c|c|c|c|c|c|c|c|c|c|}
\hline & \multicolumn{3}{|c|}{ Placebo $(n=15)$} & \multicolumn{3}{|c|}{ PBMT-sMF $(n=15)$} & \multirow[b]{2}{*}{$\begin{array}{c}\text { Between } \\
\text { Groups } \\
\text { Comparisons }\end{array}$} & \multirow[b]{2}{*}{$\begin{array}{c}\text { Mean } \\
\text { Difference } \\
{[95 \% \mathrm{Cl}]}\end{array}$} & \multirow[b]{2}{*}{$\begin{array}{c}\text { Effect Size } \\
\text { Cohen d }\end{array}$} \\
\hline & Baseline & Day 10 & Endpoint & Baseline & Day 10 & Endpoint & & & \\
\hline Platelets $\left(\mathrm{mm}^{3}\right)$ & $\begin{array}{c}189,800.00 \\
( \pm \\
92,499.57)\end{array}$ & $\begin{array}{c}237,890.86 \\
( \pm \\
71,588.08)\end{array}$ & $\begin{array}{c}231,266.66 \\
( \pm \\
104,779.67)\end{array}$ & $\begin{array}{c}210,028.26 \\
( \pm \\
90,254.29)\end{array}$ & $\begin{array}{c}261,858.03 \\
( \pm \\
145,159.59)\end{array}$ & $\begin{array}{c}288,800.00 \\
( \pm \\
166,270.09)\end{array}$ & $\begin{array}{l}\text { Baseline: } p=0.99 \\
\text { Day 10: } p=0.99 \\
\text { Endpoint: } p=0.54\end{array}$ & $\begin{array}{c}\text { Baseline: } \\
20,228 \\
{[-83,748 \text { to }} \\
\text { 124,204] } \\
\text { Day 10: } \\
23,967 \\
{[-80,009 \text { to }} \\
\text { 127,943] } \\
\text { Endpoint: } \\
57,533 \\
{[-46,443 \text { to }} \\
\text { 161,509] }\end{array}$ & $\begin{array}{l}\text { Day I0: } 0.2 \\
\quad \text { (small) } \\
\text { Endpoint: } 0.4 \\
\text { (small) }\end{array}$ \\
\hline
\end{tabular}

Notes: *Intragroup difference (PBMT-sMF) compared to the baseline $(p<0.05)$; ${ }^{\$} *$ Intragroup difference (PBMT-sMF) compared to the Day 10 ( $\left.p<0.01\right)$; **Intragroup difference (PBMT-sMF) compared to the baseline ( $p<0.01)$; " Intragroup difference (Placebo) compared to the baseline ( $p<0.05$; ${ }^{\#}$ Intragroup difference (Placebo) compared to baseline $(P<0.01)$. Continuous variables are expressed as mean (standard deviation).

Abbreviations: PBMT-sMF, photobiomodulation therapy combined with static magnetic field; Cl, confidence interval; CRP, C-reactive protein; TNF-alpha, tumor necrosis factor.

\section{Discussion}

This is the first randomized, triple-blinded, placebocontrolled trial evaluating the effects of PBMT-sMF in severe COVID-19 patients requiring mechanical ventilation. The length of ICU stay was observed to be shorter in the PBMT-sMF group than in the placebo group, but with no significant difference. In addition, the PBMT-sMF group demonstrated increased diaphragm thickness and the improvement in several ventilatory parameters and biochemical markers.

Although there is speculation about the possible benefits of PBMT (isolated or combined with SMF) in COVID-19 patients, ${ }^{53}$ our study is the only randomized controlled trial on this topic to date. Several clinical studies with low levels of evidence have reported on the use of PBMT in COVID-19 patients. Two case reports described the reduction of inflammatory markers such as IL-6, ferritin, and CRP with the use of PBMT in severe COVID-19 patients. Moreover, improvement in radiological findings, reduction in lung involvement, and increase in oxygen saturation have been observed. ${ }^{54,55}$ A small open label study $(n=10)$ demonstrated that patients treated with PBMT showed improvement in pulmonary indices such as the SMART-COP score for pneumonia severity, the Brescia-COVID respiratory severity scale (BCRSS) score, the radiographic assessment of lung edema (RALE) scale score, and the Community-Acquired Pneumonia (CAP) score, in addition to a rapid recovery from COVID-19. ${ }^{56}$ Although the aforementioned studies were carried out in severe COVID-19 patients, the profile of patients treated in our study was different, as we included only severely ill COVID-19 ICU patients requiring orotracheal intubation due to respiratory failure. In addition, the measured outcomes, irradiation protocols, and PBMT parameters involved in previous studies were different to those applied in our randomized controlled trial. Finally, isolated PBMT, instead of PBMT-sMF, were employed in previous studies. Heterogeneity in these characteristics, therefore, limited the direct comparison among the studies.

In our study, we observed that the use of PBMT-sMF not only increased muscle thickness and muscle strength, ${ }^{57-59}$ but also prevented atrophy due to disuse, ${ }^{34}$ as previously observed in skeletal muscles. In addition, there is evidence that PBMT modulates inflammatory processes by decreasing the CRP levels in skeletal muscles, ${ }^{60,61}$ which was also observed in our study. With regards to treatments other than PBMT, it has been shown that the time taken for patients treated with lopinavir-ritonavir to achieve clinical improvement was similar to that for patients treated with standard care alone. ${ }^{9}$ In addition, the time to achieve clinical improvement within 28 days following treatment with combined convalescent plasma therapy and standard treatment was similar to those following standard treatment alone. ${ }^{62}$ In 
contrast, patients treated with remdesivir showed shorter recovery times than those treated with placebo. ${ }^{10}$ In our trial, patients treated with PBMT-sMF also had shorter recovery times, but with no significant difference compared to the placebo group, probably due to the small sample size. It is important to highlight that we included only ICU patients requiring invasive mechanical ventilation, which is distinct from the aforementioned studies. 9,10,62 Finally, we did not observe any adverse effects with the use of PBMTsMF, while treatment involving convalescent plasma therapy, lopinavir-ritonavir, and remdesivir have been associated with adverse effects such as gastrointestinal events, chills, rashes, acute kidney injury, and even severe respiratory failure. ${ }^{9,10,62}$

PBMT-sMF associated with improvements in the ventilatory parameters, inflammatory and infectious processes, and immune responses of severe COVID-19 patients requiring mechanical ventilation. It was previously observed that such patients presented with elevated ventilation-perfusion mismatch due to high dead space fraction. ${ }^{63}$ In our study, higher ventilation/perfusion ratio with preservation and improvement of diaphragm thickness were observed in patients treated with PBMT-sMF. These improvements possibly led to decreased inflammation and infection (as reflected by CRP level), which enhanced the immune response (as reflected by lymphocyte count). These findings suggest that the preservation of the main respiratory muscle may trigger a cascade of positive effects and improve the clinical condition of patients. Furthermore, patients in the PBMT-sMF group also demonstrated shorter lengths of ICU stay, suggesting that PBMT-sMF may reduce the burdens of both the hospital and the healthcare system and minimize the use of scarce healthcare resources during the pandemic. In addition, PBMT-sMF has proven to be safe, with no adverse effects observed. In addition, the mortality rate of the PBMTsMF group was lower than that of the placebo group, although with no statistical significance.

This trial was prospectively registered. True randomization, concealment allocation, and blinding of the therapists, outcome assessors, and patients were employed. Statistical analysis was conducted following the intention-to-treat principle and was performed by a researcher blinded to the treatment allocations. Moreover, a placebo group was used to control for confounders such as the placebo effect, regression to mean, and natural recovery. Although attempts were made to minimize bias, this study had several limitations. There were two deviations from the registered protocol. First, we estimated that the study endpoint would be up to 20 days after randomization. However, as the endpoint directly depended on the length of ICU stay, the study period of some cases extended beyond 20 days. The second deviation involved the lack of evaluations on $\mathrm{IgG}, \mathrm{IgM}$, and D-dimer levels due to failures at the laboratory in charge in implementing the necessary routines before the beginning of our trial. In addition, the lack of post-discharge follow-ups and the small sample size were other limitations of our study.

This trial is the first to assess the effects of PBMT-sMF in severe COVID-19 patients; therefore, the required sample size for precise comparison of the primary outcome was unknown a priori. However, this study presents as a guide for the estimation of appropriate sample sizes for future studies with length of ICU stay as a primary outcome. Based on our results, we estimated that 68 patients per group would be required in future studies to detect a significant difference. Therefore, rigorous methodological quality assessments and adequate sample sizes are warranted to investigate whether PBMT-sMF decreases the length of ICU stay in severe COVID-19 ICU patients requiring invasive mechanical ventilation. In addition, post-ICU discharge follow-ups should be considered in future randomized controlled trials to observe the medium- and long-term effects, as well as the adverse effects, of PBMT-sMF in severe COVID-19 patients. Moreover, future studies should investigate whether modifying the power output of the ultrasound device while measuring for diaphragm thickness could increase the effect size of PBMT-sMF. Finally, different treatment protocols should be trialed to achieve better results with the use of PBMT-sMF in severe COVID-19 patients.

\section{Conclusion}

PBMT-sMF failed to show superiority to the placebo in decreasing the length of ICU stay in severe COVID-19 patients requiring invasive mechanical ventilation, although our sample size may have been underpowered to detect a significant difference. However, PBMT-sMF is associated with increased diaphragm thickness, $\mathrm{PO}_{2} / \mathrm{FiO}_{2}$ ratio, and lymphocyte count and decreased $\mathrm{FiO}_{2}, \mathrm{CRP}$ levels, and hemoglobin count.

\section{Abbreviations}

COVID-19, Coronavirus disease; CRP, C-reactive protein; IL, Interleukin; TNF, Tumor necrosis factor; ICU, Intensive care unit; PBMT, Photobiomodulation therapy; sMF, Static magnetic field; LASER, Light amplification by stimulated emission of radiation; LEDs, light-emitting diodes; ATP, Adenosine triphosphate; PBMT-sMF, Photobiomodulation 
therapy combined with static magnetic field; $\mathrm{IgG}$, Immunoglobulin G; IgM, Immunoglobulin M; RT-PCR, Reverse transcription-polymerase chain reaction; PEEP, Positive end-expiratory pressure; SAPS 3, Simplified Acute Physiology Score 3; $\mathrm{FiO}_{2}$, Fraction of inspired oxygen; $\mathrm{PO}_{2}$, Arterial partial pressure of oxygen; $\mathrm{PO}_{2} / \mathrm{FiO}_{2}$ ratio, Ratio of arterial partial pressure of oxygen and fraction of inspired oxygen; SD, Standard deviation; MD, Mean difference; CI, Confidence interval; BCRSS, Brescia-COVID respiratory severity scale; RALE, Radiographic assessment of lung edema; CAP, Community-Acquired Pneumonia.

\section{Data Sharing Statement}

The datasets used and/or analyzed in the study are available from the corresponding author on reasonable request.

\section{Ethics Approval and Informed Consent}

This study was submitted and approved by the Research Ethics Committee of Associação Dr. Bartholomeu Tacchini/Hospital Tacchini/RS (protocol number: 3,985,226), and by the National Research Ethics Commission of the Brazilian Ministry of Health (protocol number: 4,021,485). All eligible patients or their legal representatives (if the patients were too unwell to provide consent) were informed of the study objectives and provided written informed consent before enrollment.

\section{Acknowledgment}

The authors thank the entire multidisciplinary team that worked in the ICU of Hospital Tacchini, the Tacchini Institute for Health Research, and Marcos Vinícius Ferlito and Tauani de Souza for their contributions.

\section{Funding}

Multi Radiance Medical (Solon, OH, USA) provided financial support and therapeutic devices for this study. Professor Ernesto Cesar Pinto Leal-Junior receives grants (\#310281/2017-2) from the Brazilian Council of Science and Technology Development (CNPq). Multi Radiance Medical and $\mathrm{CNPq}$ had no role in the planning, conducting, and analysis of the data.

\section{Disclosure}

Professor Ernesto Cesar Pinto Leal-Junior receives research support from Multi Radiance Medical (Solon, $\mathrm{OH}$, USA), a laser device manufacturer. Professor
Ernesto Cesar Pinto Leal-Junior also has a patent Laser therapy for patients requiring mechanical ventilation pending to Multi Radiance Medical. Shaiane Silva Tomazoni has a personal relationship with Ernesto Cesar Pinto LealJunior. Multi Radiance Medical had no role in the planning, conducting, and analysis of the data. The remaining authors declare that they have no support from any organizations for the submitted work; no financial relationships with any organizations that might have an interest in the submitted work in the past three years; and no other relationships or activities that could appear to have influenced the submitted work.

\section{References}

1. World Health Organization (WHO). Report of the WHO-China Joint Mission on coronavirus disease 2019 (COVID-19). Available from https:/www.who.int/docs/default-source/coronaviruse/who-chinajoint-mission-on-covid-19-final-report.pdf. Accessed May 25, 2020.

2. Huang C, Wang Y, Li X, et al. Clinical features of patients infected with 2019 novel coronavirus in Wuhan, China. Lancet. 2020;395 (10223):497-506. doi:10.1016/S0140-6736(20)30183-5

3. Israelsen SB, Kristiansen KT, Hindsberger B, et al. Characteristics of patients with COVID-19 pneumonia at Hvidovre Hospital, March-April 2020. Dan Med J. 2020;67(6):A05200313.

4. Petrilli CM, Jones SA, Yang J, et al. Factors associated with hospital admission and critical illness among 5279 people with coronavirus disease 2019 in New York City: prospective cohort study. BMJ. 2020;369:m1966. doi:10.1136/bmj.m1966

5. Wang D, Hu B, Hu C, et al. Clinical characteristics of 138 hospitalized patients with 2019 novel coronavirus-infected pneumonia in Wuhan, China. JAMA. 2020;323(11):1061-1069. doi:10.1001/jama.2020.1585

6. Wu C, Chen X, Cai Y, et al. Risk factors associated with acute respiratory distress syndrome and death in patients with coronavirus disease 2019 pneumonia in Wuhan, China. JAMA Intern Med. 2020;180(7):934-943. doi:10.1001/jamainternmed.2020.0994

7. Richardson S, Hirsch JS, Narasimhan M, et al. Presenting characteristics, comorbidities, and outcomes among 5700 patients hospitalized with COVID-19 in the New York city area. JAMA. 2020;323 (20):2052-2059. doi:10.1001/jama.2020.6775

8. Tang W, Cao Z, Han M, et al. Hydroxychloroquine in patients with mainly mild to moderate coronavirus disease 2019: open label, randomised controlled trial. BMJ. 2020;369:m1849. doi:10.1136/bmj.m1849

9. Cao B, Wang Y, Wen D, et al. A Trial of lopinavir-ritonavir in adults hospitalized with severe Covid-19. $N$ Engl J Med. 2020;382 (19):1787-1799. doi:10.1056/NEJMoa2001282

10. Beigel JH, Tomashek KM, Dodd LE, et al. Remdesivir for the treatment of Covid-19 - final report. $N$ Engl J Med. 2020;383 (19):1813-1826. doi:10.1056/NEJMoa2007764

11. Tomazini BM, Maia IS, Cavalcanti AB, et al. Effect of dexamethasone on days alive and ventilator-free in patients with moderate or severe acute respiratory distress syndrome and COVID-19: the CoDEX Randomized Clinical Trial. JAMA. 2020;324 (13):1307-1316. doi:10.1001/jama.2020.17021

12. Wilcox SR. Management of respiratory failure due to covid-19. BMJ. 2020;369:m1786. doi:10.1136/bmj.m1786

13. Wu Z, McGoogan JM. Characteristics of and important lessons from the coronavirus disease 2019 (COVID-19) outbreak in China: summary of a report of 72314 cases from the Chinese center for disease control and prevention. JAMA. 2020;323(13):1239-1242. doi:10.1001/jama.2020.2648 
14. Price S, Singh S, Ledot S, et al. Respiratory management in severe acute respiratory syndrome coronavirus 2 infection. Eur Heart $J$ Acute Cardiovasc Care. 2020;9(3):229-238. doi:10.1177/ 2048872620924613

15. Wujtewicz M, Dylczyk-Sommer A, Aszkiełowicz A, Zdanowski S, Piwowarczyk S, Owczuk R. COVID-19 - what should anaethesiologists and intensivists know about it? Anaesthesiol Intensive Ther. 2020;52(1):34-41. doi:10.5114/ait.2020.93756

16. Lazzeri M, Lanza A, Bellini R, et al. Respiratory physiotherapy in patients with COVID-19 infection in acute setting: a position paper of the Italian Association of Respiratory Physiotherapists (ARIR). Monaldi Arch Chest Dis. 2020;90(1). doi:10.4081/ monaldi.2020.1285.

17. Dres M, Goligher EC, Heunks LMA, Brochard LJ. Critical illness-associated diaphragm weakness. Intensive Care Med. 2017;43(10):1441-1452. doi:10.1007/s00134-017-4928-4

18. Dres M, Jung B, Molinari N, et al. Respective contribution of intensive care unit-acquired limb muscle and severe diaphragm weakness on weaning outcome and mortality: a post hoc analysis of two cohorts. Crit Care. 2019;23(1):370. doi:10.1186/s13054-019-2650-z

19. Goligher EC, Dres M, Fan E, et al. Mechanical ventilation-induced diaphragm atrophy strongly impacts clinical outcomes. Am J Respir Crit Care Med. 2018;197(2):204-213. doi:10.1164/rccm.2017030536OC

20. Jonkman AH, Jansen D, Heunks LM. Novel insights in ICU-acquired respiratory muscle dysfunction: implications for clinical care. Crit Care. 2017;21(1):64. doi:10.1186/s13054-017-1642-0

21. Bissett B, Leditschke IA, Paratz JD, Boots RJ. Respiratory dysfunction in ventilated patients: can inspiratory muscle training help? Anaesth Intensive Care. 2012;40(2):236-246. doi:10.1177/ 0310057X1204000205

22. Daniel Martin A, Smith BK, Gabrielli A. Mechanical ventilation, diaphragm weakness and weaning: a rehabilitation perspective. Respir Physiol Neurobiol. 2013;189(2):377-832. doi:10.1016/j. resp.2013.05.012

23. Leal-Junior ECP, Lopes-Martins RÁB, Bjordal JM. Clinical and scientific recommendations for the use of photobiomodulation therapy in exercise performance enhancement and post-exercise recovery: current evidence and future directions. Braz $J$ Phys Ther. 2019;23(1):71-75. doi:10.1016/j.bjpt.2018.12.002

24. Albuquerque-Pontes GM, Vieira RP, Tomazoni SS, et al. Effect of pre-irradiation with different doses, wavelengths, and application intervals of low-level laser therapy on cytochrome c oxidase activity in intact skeletal muscle of rats. Lasers Med Sci. 2015;30(1):59-66. doi:10.1007/s10103-014-1616-2

25. Suardi N, Sodipo BK, Mustafa MZ, Ali Z. Effect of visible laser light on ATP level of anaemic red blood cell. J Photochem Photobiol B. 2016;162:703-706. doi:10.1016/j.jphotobiol.2016.07.041

26. Keszler A, Lindemer B, Hogg N, Weihrauch D, Lohr NL. Wavelength-dependence of vasodilation and NO release from S-nitrosothiols and dinitrosyl iron complexes by far red/near infrared light. Arch Biochem Biophys. 2018;649:47-52. doi:10.1016/j. abb.2018.05.006

27. Linares SN, Beltrame T, Ferraresi C, Galdino GAM, Catai AM. Photobiomodulation effect on local hemoglobin concentration assessed by near-infrared spectroscopy in humans. Lasers Med Sci. 2020;35(3):641-649. doi:10.1007/s10103-019-02861-x

28. Chen YC, Su YH, Lin YT, Huang CC, Hwang IS. Acute physiological responses to combined blood flow restriction and low-level laser. Eur J Appl Physiol. 2020;120(6):1437-1447. doi:10.1007/s00421020-04378-6

29. De Marchi T, Leal Junior EC, Bortoli C, Tomazoni SS, LopesMartins RA, Salvador M. Low-level laser therapy (LLLT) in human progressive-intensity running: effects on exercise performance, skeletal muscle status, and oxidative stress. Lasers Med Sci. 2012;27 (1):231-236. doi:10.1007/s10103-011-0955-5
30. Sakurai Y, Yamaguchi M, Abiko Y. Inhibitory effect of low-level laser irradiation on LPS-stimulated prostaglandin E2 production and cyclooxygenase-2 in human gingival fibroblasts. Eur J Oral Sci. 2000;108(1):29-34. doi:10.1034/j.1600-0722.2000.00783.x

31. Langella LG, Casalechi HL, Tomazoni SS, et al. Photobiomodulation therapy (PBMT) on acute pain and inflammation in patients who underwent total hip arthroplasty-a randomized, triple-blind, placebo-controlled clinical trial. Lasers Med Sci. 2018;33 (9):1933-1940. doi:10.1007/s10103-018-2558-x

32. Tomazoni SS, Costa LOP, Joensen J, et al. Photobiomodulation therapy is able to modulate $\mathrm{PGE}_{2}$ levels in patients with chronic non-specific low back pain: a randomized placebo-controlled trial. Lasers Surg Med. 2021;53(2):236-244. doi:10.1002/1sm.23255

33. Grandinétti Vdos S, Miranda EF, Johnson DS, et al. The thermal impact of phototherapy with concurrent super-pulsed lasers and red and infrared LEDs on human skin. Lasers Med Sci. 2015;30 (5):1575-1581. doi:10.1007/s10103-015-1755-0

34. de Paiva PRV, Casalechi HL, Tomazoni SS, et al. Does the combination of photobiomodulation therapy (PBMT) and static magnetic fields (sMF) potentiate the effects of aerobic endurance training and decrease the loss of performance during detraining? A randomised, triple-blinded, placebo-controlled trial. BMC Sports Sci Med Rehabil. 2020;12(1):23. doi:10.1186/s13102-020-00171-2

35. Okano H. Effects of static magnetic fields in biology: role of free radicals. Front Biosci. 2008;13:6106-6125. doi:10.2741/3141

36. Friedmann H, Lipovsky A, Nitzan Y, Lubart R. Combined magnetic and pulsed laser fields produce synergistic acceleration of cellular electron transfer. Laser Ther. 2009;18:137-141. doi:10.5978/ islsm. 18.137

37. Wang D, Wang Z, Zhang L, et al. Cellular ATP levels are affected by moderate and strong static magnetic fields. Bioelectromagnetics. 2018;39(5):352-360. doi:10.1002/bem.22122

38. Coballase-Urrutia E, Navarro L, Ortiz JL, et al. Static magnetic fields modulate the response of different oxidative stress markers in a restraint stress model animal. Biomed Res Int. 2018;2018:3960408. doi:10.1155/2018/3960408

39. Weintraub MI, Wolfe GI, Barohn RA, et al. Static magnetic field therapy for symptomatic diabetic neuropathy: a randomized, double-blind, placebo-controlled trial. Arch Phys Med Rehabil. 2003;84(5):736-746. doi:10.1016/S0003-9993(03)00106-0

40. Li S, Yu B, Zhou D, He C, Zhuo Q, Hulme JM. Electromagnetic fields for treating osteoarthritis. Cochrane Database Syst Rev. 2013;12:CD003523.

41. Fan Y, Ji X, Zhang L, Zhang X. The analgesic effects of static magnetic fields. Bioelectromagnetics. 2021;42(2):115-127. doi:10.1002/bem.22323

42. Leal-Junior EC, Vanin AA, Miranda EF, de Carvalho Pde T, Dal Corso S, Bjordal JM. Effect of phototherapy (low-level laser therapy and light-emitting diode therapy) on exercise performance and markers of exercise recovery: a systematic review with meta-analysis. Lasers Med Sci. 2015;30(2):925-939. doi:10.1007/s10103-013-1465-4

43. Vanin AA, Verhagen E, Barboza SD, Costa LOP, Leal-Junior ECP. Photobiomodulation therapy for the improvement of muscular performance and reduction of muscular fatigue associated with exercise in healthy people: a systematic review and meta-analysis. Lasers Med Sci. 2018;33(1):181-214. doi:10.1007/s10103-017-2368-6

44. de Souza GHM, Ferraresi C, Moreno MA, et al. Acute effects of photobiomodulation therapy applied to respiratory muscles of chronic obstructive pulmonary disease patients: a double-blind, randomized, placebo-controlled crossover trial. Lasers Med Sci. 2020;35 (5):1055-1063. doi:10.1007/s10103-019-02885-3

45. de Lima FM, Vitoretti L, Coelho F, et al. Suppressive effect of low-level laser therapy on tracheal hyperresponsiveness and lung inflammation in rat subjected to intestinal ischemia and reperfusion. Lasers Med Sci. 2013;28(2):551-564. doi:10.1007/s10103-012-1088-1 
46. Aimbire F, Bjordal JM, Iversen VV, et al. Low level laser therapy partially restores trachea muscle relaxation response in rats with tumor necrosis factor alpha-mediated smooth airway muscle dysfunction. Lasers Surg Med. 2006;38(8):773-778. doi:10.1002/1sm.20357

47. Silva VR, Marcondes P, Silva M, et al. Low-level laser therapy inhibits bronchoconstriction, Th2 inflammation and airway remodeling in allergic asthma. Respir Physiol Neurobiol. 2014;194:37-48. doi:10.1016/j.resp.2014.01.008

48. Silva Junior JM, Malbouisson LM, Nuevo HL, et al. Applicability of the simplified acute physiology score (SAPS 3) in Brazilian hospitals. Rev Bras Anestesiol. 2010;60(1):20-31. doi:10.1590/S003470942010000100003

49. Magalhães PAF, Camillo CA, Langer D, Andrade LB, Duarte MDCMB, Gosselink R. Weaning failure and respiratory muscle function: what has been done and what can be improved? Respir Med. 2018;134:54-61. doi:10.1016/j.rmed.2017.11.023

50. Sklar MC, Dres M, Fan E, et al. Association of low baseline diaphragm muscle mass with prolonged mechanical ventilation and mortality among critically ill adults. JAMA Netw Open. 2020;3(2): e1921520. doi:10.1001/jamanetworkopen.2019.21520

51. Hollis S, Campbell F. What is meant by intention to treat analysis? Survey of published randomised controlled trials. BMJ. 1999;319 (7211):670-674. doi:10.1136/bmj.319.7211.670

52. Elkins MR, Moseley AM. Intention-to-treat analysis. J Physiother. 2015;61(3):165-167. doi:10.1016/j.jphys.2015.05.013

53. Fernandes AB, de Lima CJ, Villaverde AGJB, Pereira PC, Carvalho HC, Zângaro RA. Photobiomodulation: shining light on COVID-19. Photobiomodul Photomed Laser Surg. 2020;38 (7):395-397. doi:10.1089/photob.2020.4882

54. Sigman SA, Mokmeli S, Vetrici MA. Adjunct low level laser therapy (LLLT) in a morbidly obese patient with severe COVID-19 pneumonia: a case report. Can J Respir Ther. 2020;56:52-56. doi:10.29390/ cjrt-2020-022

55. Sigman SA, Mokmeli S, Monici M, Vetrici MA. A 57-year-old african american man with severe COVID-19 Pneumonia who responded to supportive photobiomodulation Therapy (PBMT): first Use of PBMT in COVID-19. Am J Case Rep. 2020;21:e926779. doi:10.12659/AJCR.926779

56. Vetrici MA, Mokmeli S, Bohm AR, Monici M, Sigman SA. Evaluation of adjunctive photobiomodulation (PBMT) for COVID-19 pneumonia via clinical status and pulmonary severity indices in a preliminary trial. J Inflamm Res. 2021;14:965-979. doi:10.2147/JIR.S301625
57. Vanin AA, Miranda EF, Machado CS, et al. What is the best moment to apply phototherapy when associated to a strength training program? A randomized, double-blinded, placebo-controlled trial: phototherapy in association to strength training. Lasers Med Sci. 2016;31(8):1555-1564. doi:10.1007/ s10103-016-2015-7

58. Baroni BM, Rodrigues R, Freire BB, Franke Rde A, Geremia JM, Vaz MA. Effect of low-level laser therapy on muscle adaptation to knee extensor eccentric training. Eur J Appl Physiol. 2015;115 (3):639-647. doi:10.1007/s00421-014-3055-y

59. Leal-Junior ECP, de Oliveira MFD, Joensen J, Stausholm MB, Bjordal JM, Tomazoni SS. What is the optimal time-response window for the use of photobiomodulation therapy combined with static magnetic field (PBMT-sMF) for the improvement of exercise performance and recovery, and for how long the effects last? A randomized, triple-blinded, placebo-controlled trial. $B M C$ Sports Sci Med Rehabil. 2020;12(1):64.

60. Leal Junior EC, Lopes-Martins RA, Rossi RP, et al. Effect of cluster multi-diode light emitting diode therapy (LEDT) on exercise-induced skeletal muscle fatigue and skeletal muscle recovery in humans. Lasers Surg Med. 2009;41(8):572-577. doi:10.1002/1sm.20810

61. Leal Junior EC, Lopes-Martins RA, Frigo L, et al. Effects of low-level laser therapy (LLLT) in the development of exercise-induced skeletal muscle fatigue and changes in biochemical markers related to postexercise recovery. J Orthop Sports Phys Ther. 2010;40(8):524-532. doi:10.2519/jospt.2010.3294

62. Li L, Zhang W, Hu Y, et al. Effect of convalescent plasma therapy on time to clinical improvement in patients with severe and life-threatening COVID-19: a randomized clinical trial. JAMA. 2020;324(5):460-470. doi:10.1001/jama.2020.10044

63. Mauri T, Spinelli E, Scotti E, et al. Potential for lung recruitment and ventilation-perfusion mismatch in patients with the acute respiratory distress syndrome from coronavirus disease 2019. Crit Care Med. 2020;48(8):1129-1134. doi:10.1097/ CCM.0000000000004386
Journal of Inflammation Research

\section{Publish your work in this journal}

The Journal of Inflammation Research is an international, peerreviewed open-access journal that welcomes laboratory and clinical findings on the molecular basis, cell biology and pharmacology of inflammation including original research, reviews, symposium reports, hypothesis formation and commentaries on: acute/chronic inflammation; mediators of inflammation; cellular processes; molecular mechanisms; pharmacology and novel anti-inflammatory drugs; clinical conditions involving inflammation. The manuscript management system is completely online and includes a very quick and fair peerreview system. Visit http://www.dovepress.com/testimonials.php to read real quotes from published authors. 